S. Drobyazko, Candidate of Economic Sciences, Associate Professor, Professor Department of Finance and Accounting, Open University of Human Development "Ukraine", Kyiv, Ukraine

\title{
METHODOLOGICAL ASPECTS OF DEVELOPMENT OF THE ASSESSMENT SYSTEM OF ECONOMIC SECURITY OF INSURANCE SECTOR ENTERPRISES
}

\author{
C. I. Аробязко, \\ к. е. н., доцент, професор кафедри обліку та фінансів, \\ Відкритий міжнародний університет розвитку людини "Україна", м. Київ
}

\section{МЕТОАИЧНІ АСПЕКТИ ФОРМУВАННЯ СИСТЕМИ ОЦІНЮВАННЯ ЕКОНОМІЧНОЇ БЕЗПЕКИ ПІАПРИЕМСТВ СТРАХОВОГО СЕКТОРУ}

The purpose of the article is to develop theoretical, methodological and practical recommendations for assessing the economic security of enterprises. The system of assessing the economic security of enterprises is based on the calculation of the integral index consisting of four stages: preparatory, expert evaluation of the choice of indicators on the basis of the method of pairwise equation, calculation of the integral index of economic security, formation of the results of the calculation of the integral indicator of economic security assessment. The peculiarities of conducting expert analysis during the formation of a system of indicators of the integral indicator of economic security assessment on the basis of the competence approach, taking into account the rank of positions, are considered. It is proved that in order to determine the competence of experts it is necessary to evaluate the following qualities: competence, creativity, attitude to examination, conformism, analyticity, collectivism, self-criticism, reliability. The construction of the Fishbone Diagram of economic security factors has allowed the indicators to be determined by stimulants and stimulants. A system of indicators of economic security assessment of enterprises is formed, consisting of four blocks: "Financial"; "Information"; "Personnel"; "Marketing". It is proved that the information base for calculating the integral indicator of economic security assessment is the data of financial and statistical reporting of enterprises, the State Statistics Service of Ukraine, statistical collections of committees and departments of state power, and the Ministry of Economy of Ukraine. The calculation of integral indicator of economic security assessment is considered, which is considered as a quantitative measure of enterprise activity, which provides economic protection for various components. The use of the integral indicator enables to increase the objectivity of assessing the measures to ensure economic security, which directly affects the efficiency of the insurance sector enterprises. Prospects for further research are the elaboration of a matrix of corrective measures for relevant areas of change in the existing system of economic security management at enterprises.

Метою статті є розробка теоретичних, методологічних положень та практичних рекомендацій щодо оцінювання економічної безпеки підприємств. Запропоновано систему оцінювання економічної безпеки підприємств на основі розрахунку інтегрального показника, що складається з чотирьох етапів: підготовчий, експертна оцінка вибору показників на засаАах методу попарного рівняння, розрахунок інтегрального показника економічної безпеки, формування результатів розрахунку інтегрального показника оцінювання економічної безпеки. Розглянуто особливості проведення експертного аналізу при формуванні системи показників інтегрального показника оцінювання економічної безпеки на засадах компетентнісного підходу з урахуванням рангів посаА. Аоведено, що Аля визначення компетенції експертів необхідно оцінити такі якості: компетенція, креативність, відношення до експертизи, конформізм, аналітичність, колективізм, самокритичність, достовірність. Побудова Fishbone Diagram факторів економічної безпеки дозволила визначити показники стимуляторами та дестимулятори. Сформована система показників оцінювання економічної безпеки підприємств, що складається з чотирьох блоків: "Фінансова"; "Інформаційна"; "КаАрова"; 
"Маркетингова". Аоведено, що інформаційною базою для розрахунку інтегрального показника оцінювання економічної безпеки є Аані фінансової та статистичної звітності підприємств, Аержавної служби статистики України, статистичні збірники комітетів та департаментів державної влади, Міністерства економіки України. Наведено розрахунок інтегрального показника оцінювання економічної безпеки, який розглядається як кількісна міра діяльності підприємства, що забезпечує економічну захищеність за різними складовими. Застосування інтегрального показника дає можливість збільшити об'єктивність оцінки заходів забезпечення економічної безпеки, що безпосереАньо впливає на ефективність діяльності підприємств страхового сектору. Перспективами подальших досліджень $\epsilon$ розробка матриці коригуючих заходів релевантних напрямів зміни існуючої системи управління економічної безпеки на підприємствах.

Key words: structural-logical model, economic security, controlling mechanism. Ключові слова: структурно-логічна модель, економічна безпека, механізм управління.

\section{INTRODUCTION}

The economic security strategy, when formulating goals and indicating objects, should include the characterization of external and internal threats; definition of criteria and parameters (threshold values) of indicators characterizing the interests of enterprises and meet the requirements of economic security; development of economic policy, including mechanisms of factors that influence the state of economic security; the line of action on the strategy implementation.

The study of the main approaches to assessing the economic security level of enterprises confirms that each of the methods we have reviewed has certain limitations in the use, and therefore it does not give us a possibility to fully and accurately determine the existing situation [1-3]. Indicator and resource-functional approaches are the most widespread in order to assess the economic security level [4-5]. In this case, assessing the economic security is reduced to the assessment of the quality of enterprises by comparing the value of the indicators calculated for a certain given time with the values of previous moments or critical ones.

The purpose of the article is to develop theoretical, methodological and practical recommendations for assessing the economic security of enterprises.

The assessment system of economic security is an important component of ensuring the economic security of the insurance sector enterprises. It makes sense to highlight the key parameters of the economic security of a tourist enterprise, which are gathered in 4 groups:
Group 1 "Financial" $S_{\text {fin }}$ (coverage ratio of losses at the expense of reserves; coverage level of insured losses; debt-to-equity ratio, $\mathrm{D} / \mathrm{E}$; profitability index of insurance products; tax burden);

Group 2 "Personnel" $S_{\text {pers }}$ (average wage index; personnel development of the enterprise; coefficient of personnel stability; coefficient of managerial load; personnel turnover);

Group 3 "Informational" $S_{\text {inf }}$ (level of technical and informational support of the enterprise; level of communication within the enterprise (level of feedback); the level of introduction of Internet technologies at the enterprise; coefficient of use of e-commerce in the activity; ratio of the amount of bonus payments for the ideas presented, innovative proposals, new solutions to the total amount of bonus payments per company);

Group 4 "Marketing" $S_{\text {mark }}$ (novelty (renewal) of the assortment of insurance services; business reputation of the enterprise; market share, controlled by the enterprise (by segments); commitment of consumers of insurance services; ratio of marketing costs to total costs).

In order to assess the state of economic security of the insurance sector enterprises, a system of indicators (key parameters) is needed. It would create a formalized basis for making managerial decisions that would express the strategic interests of the enterprise and ensure an adequate level of its economic security.

Development of the assessment system of economic security, balanced from the standpoint of accuracy, objectivity, relevancy, simplicity, convenience and comprehensiveness is a complex multidimensional process [6-7]. 


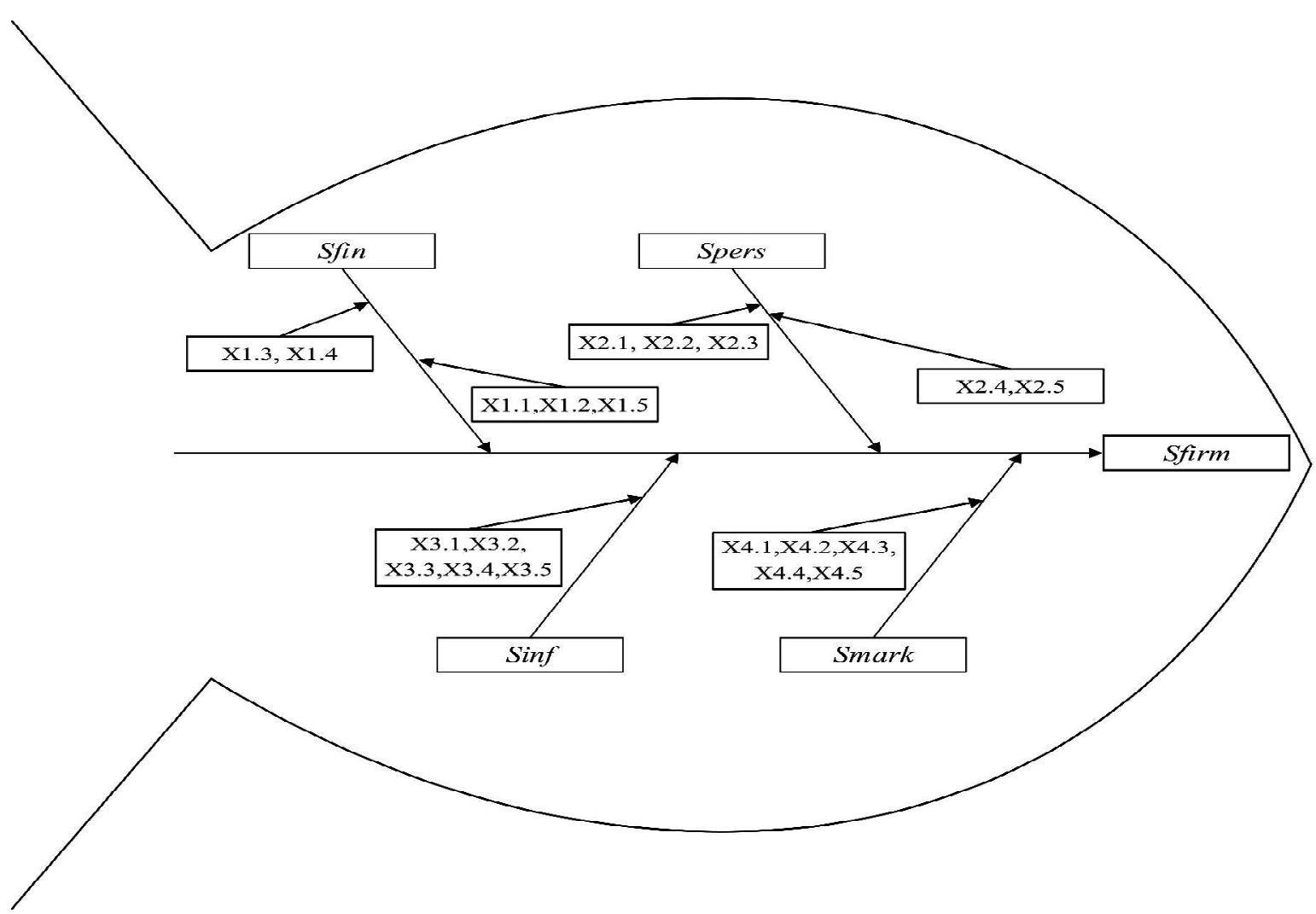

Figure 1. Fishbone Diagram of the assessment system of economic security of enterprises $\left(S_{\text {firm }}\right)$

Source: formed by the author.

Development of the assessment system of economic security consists of 4 stages.

The first stage is preparatory. It is a formation of the input data base of economic indicators for calculating the integral indicator of economic security assessment. From the analytic point of view, it is an important stage for the accuracy of the results obtained and the condition of the operation of the enterprise.

Formation of an expert group on the basis of a competency approach, taking into account the rank of positions, makes it possible to form a group that, in accordance with official duties, has the opportunity to build a system of personnel assessment in accordance with the objectives of the enterprises. Specific requirements for members of an expert group affect the principles of their selection.

In order to determine the competence of experts it is necessary to assess the following qualities: competence, creativity, attitude to examination, conformism, analyticity, collectivism, self-criticism, authenticity [5].

Thus, the competence of an expert is the level of his qualification. The competence of experts is determined using the coefficient $\mathrm{K}$, which is calculated on the basis of judgments of experts on the level of their awareness of problem solution and disclosure of the typical sources of argumentation of judgments [6].

The personal composition of the expert group consists of the total number of applicants and is formed from the most competent specialists who can demonstrate the ability to predict and identify, in our case, the patterns of the effectiveness of the implementation of individual means of economic security of enterprises.

For the purposes of study, the experts have been selected on the basis of the considerations that the employees of the higher and middle management of enterprises at $\varepsilon=0,2$ have the highest level of awareness in the subject under study.

As experts, we have selected 10 officials from different parts of the enterprise management. In the formation of a system of indicators of economic security assessment $\left(S_{\text {firm }}\right)$, an expert analysis has been used. The result of its use is the construction of the Fishbone Diagram system. The approach makes it possible to determine which indicators are incentives, and which ones are disincentives (Fig. 1).

According to the Fishbone Diagram of the assessment system of economic security of enterprises $\left(S_{\text {firm }}\right), 15$ factors of incentives (X.1.3,X1.4,X2.1,X2.2,X2.3,X3.1,X3.2,X3.3,X3.4,X3.5,X4.1,X4.2, $\mathrm{X} 4.3, \mathrm{X} 4.4, \mathrm{X} 4.5)$ and 5 factors of disincentives 
Table 1. Indicators for assessing the economic security of enterprises

\begin{tabular}{|c|c|c|c|}
\hline $\begin{array}{l}\text { Group integral } \\
\text { indicators }\end{array}$ & Indicators & $\begin{array}{c}\text { Indicator } \\
\text { symbol }\end{array}$ & Unit \\
\hline \multirow{5}{*}{$\begin{array}{l}\text { "Financial" } \\
S_{f i n}\end{array}$} & coverage ratio of losses at the expense of reserves & $\mathrm{X} 1.1$ & ratio \\
\hline & coverage level of insured losses & $\mathrm{X} 1.2$ & ratio \\
\hline & debt-to-equity ratio, $\mathrm{D} / \mathrm{E}$ & $\mathrm{X} 1.3$ & ratio \\
\hline & profitability index of insurance products & $\mathrm{X} 1.4$ & ratio \\
\hline & tax burden & $\mathrm{X} 1.5$ & ratio \\
\hline \multirow{5}{*}{$\begin{array}{l}\text { "Personnel" } \\
S_{\text {pers }}\end{array}$} & average wage index & $\mathrm{X} 2.1$ & ratio \\
\hline & personnel development of the enterprise & $\mathrm{X} 2.2$ & ratio \\
\hline & coefficient of personnel stability & $\mathrm{X} 2.3$ & ratio \\
\hline & coefficient of managerial load & $\mathrm{X} 2.4$ & ratio \\
\hline & personnel turnover & $\mathrm{X} 2.5$ & ratio \\
\hline \multirow{5}{*}{$\begin{array}{l}\text { "Informational" } \\
S_{\text {inf }}\end{array}$} & $\begin{array}{l}\text { level of technical and informational support of the } \\
\text { enterprise }\end{array}$ & $\mathrm{X} 3.1$ & ratio \\
\hline & $\begin{array}{l}\text { level of communication within the enterprise (level of } \\
\text { feedback) }\end{array}$ & $\mathrm{X} 3.2$ & ratio \\
\hline & $\begin{array}{l}\text { the level of introduction of Internet technologies at the } \\
\text { enterprise }\end{array}$ & X3.3 & ratio \\
\hline & coefficient of use of e-commerce in the activity & $\mathrm{X} 3.4$ & ratio \\
\hline & $\begin{array}{l}\text { ratio of the amount of bonus payments for the ideas } \\
\text { presented, innovative proposals, new solutions to the } \\
\text { total amount of bonus payments per company) }\end{array}$ & $\mathrm{X} 3.5$ & ratio \\
\hline \multirow[t]{5}{*}{$\begin{array}{l}\text { "Marketing" } \\
S_{\text {mark }}\end{array}$} & $\begin{array}{l}\text { novelty (renewal) of the assortment of insurance } \\
\text { services }\end{array}$ & X4.1 & ratio \\
\hline & business reputation of the enterprise & $\mathrm{X} 4.2$ & ratio \\
\hline & $\begin{array}{l}\text { market share, controlled by the enterprise (by } \\
\text { segments) }\end{array}$ & $\mathrm{X} 4.1$ & ratio \\
\hline & commitment of consumers of insurance services & $\mathrm{X} 4.1$ & ratio \\
\hline & ratio of marketing costs to total costs & $\mathrm{X} 4.1$ & ratio \\
\hline
\end{tabular}

Source: formed by the author.

(X1.1,X1.2,X1.5,X2.4,X2.5) have been separated. As we can see, each indicator has the same weight. This approach is acceptable and enables to avoid the problem of subjectivity of expert assessment in the evaluations of the integral indicator.

On the basis of Ishikawa diagram, let us determine the factors that affect economic security. With the help of experts' assessment, on the example of the component of economic security, "Finance", five factors have been separated (X1.1 is a coverage ratio of losses at the expense of reserves; coverage level of insured losses; X1.2 is a coverage level of insured losses; $\mathrm{X} 1.3$ is a debt-to-equity ratio, $\mathrm{D} / \mathrm{E} ; \mathrm{X} 1.4$ is a profitability index of insurance products; $\mathrm{X} 1.5$ is a tax burden). The considered factors are ranked according to the level of reduction of their significance.

The third stage of the development of the assessment system of economic security begins with the division of indicators into groups. Consequently, according to the determined expert assessments of the indicators of economic security, four groups have been formed according to the characteristics of security: financial, personnel, informational, marketing (Table 1).

The information base is the data of financial and statistical reporting of enterprises, the State
Statistics Service of Ukraine, statistical collections of committees and departments of state power, the Ministry of Economy of Ukraine and enterprise reporting for 2013-2017.

The generalized integral indicator of economic security assessment $S_{\text {firm }}$ is defined as the total value of group integral indicators by the formula [8]:

$$
S_{\text {frrm }}=\sum_{i=1}^{4} \beta_{i} \times S_{\text {firm }_{i}}
$$

where $\beta_{i}$ is a coefficient of influence on the value of group integral indicators of economic security assessment; $S_{f r m_{i}}$ is a group integral indicator of economic security assessment; $i$ is a number of means of economic security.

Based on the established system of indicators presented in Table 1, the calculation of the integral indicator of economic security of enterprises is carried out by the formula:

$$
\begin{aligned}
& S_{\text {firm }}=\sum_{i=1}^{4}\left(\beta_{\text {fin }} \times S_{\text {fin }}+\beta_{\text {pers }} \times S_{\text {pers }}+\beta_{\text {inf }} \times S_{\text {inf }}+\beta_{\text {mark }} \times S_{\text {mark }}\right)= \\
& =\sum_{i=1}^{4}\left(\beta_{\text {fin }} \times\left(\sum_{j=1}^{5} s_{1-5}\right)+\beta_{\text {pers }} \times\left(\sum_{e=1}^{5} s_{6-10}+\beta_{\text {inf }} \times\left(\sum_{o=1}^{5} s_{11-15}\right)+\beta_{\text {mar }} \times\left(\sum_{u=1}^{5} s_{16-20}\right)\right)\right.
\end{aligned}
$$

where $S_{\text {firm }}$ is a generalized integral indicator of economic security assessment; $I_{\text {fin }}, I_{\text {pers }}, I_{\text {inf }}, I_{\text {mark }}$ are group integral indicators of economic security assessment; $\beta_{\text {fin }}, \beta_{\text {pers }}, \beta_{\text {inf }}, \beta_{\text {mark }}$ are coefficients of influence of group integral indicators of economic security assessment of 
appropriate means (financial, personnel, informational, marketing); $s_{n}$ are indicators of economic security assessment; $i$ is a number of indicators of economic security assessment; $j$ is a number of indicators of financial means; $e$ is a number of indicators of personnel means; $o$ is a number of indicators of informational means; $u$ is a number of indicators of marketing means.

Upper and lower limits for the calculation of the integral indicator of economic security assessment $S_{\text {firm }}$ are $[0 ; 1]$.

In order to compare the indicators of different groups, we bring them to the normalized form so that changes take place in the range from 0 to 1 . For this purpose, the formula [9] is used:

$$
l_{i, j}=\left(1+e^{\frac{\bar{x}_{j}-x_{i, j}}{\sigma\left(x_{j}\right)}}\right)^{-1}
$$

where $x_{i, j}$ and $l_{i, j}$ are initial and normalized values of $j$-th indicator for $i$-th enterprise; $x_{j}$ is an average value of indicator $x_{j}$ in the sample; $\sigma$ $\left(x_{j}\right)$ is a corresponding standard deviation.

In order to calculate an average value $\left(x_{i}\right)$ and standard deviation $\sigma\left(x_{j}\right)$, we use formulas [10]:

$$
\bar{x}_{j}=\frac{\sum_{i=1}^{m} x_{i, j}}{m}, \quad \sigma\left(x_{j}\right)=\sqrt{\frac{\sum_{i=1}^{m}\left(x_{i, j}-\bar{x}_{j}\right)^{2}}{m+1}}
$$

Normalization of data enables to calculate the generalized integral indicator of economic security assessment through its components with the corresponding weighting coefficients.

Here is an example of the calculation of the group integral indicator of economic security assessment on the example of the "Knyazha" Insurance Company ("Княжа") according to the proposed methodology.

In a formalized form, the matrix of the financial component of economic security $\left(S_{\text {fin }}\right)$ is:

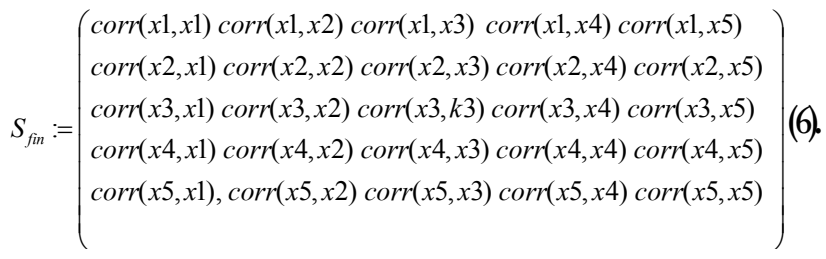

We will carry out the calculation of the matrix of the financial component of economic security $\left(S_{\text {fin }}\right)$ using 'Data Analysis' package in MS Excel:

$$
S_{\text {fin }}=\left(\begin{array}{ccccc}
1 & -0,25 & -0,68 & 0,554 & 0,56 \\
-0,25 & 1 & 0,164 & -0,226 & -0,153 \\
-0,68 & 0,164 & 1 & -0,78 & -0,611 \\
0,554 & -0,226 & -0,78 & 1 & 0,19 \\
0,56 & -0,153 & -0,611 & 0,19 & 1
\end{array}\right.
$$

According to the results of the calculation of the matrix of the financial component of economic security $\left(S_{f i n}\right)$, we can conclude: the most direct significant functional correlation is between the indicators "Profitability index of insurance products" (x4) and "Tax burden" (x5), the most inverse significant functional correlation is between the indicators "Debt-to-equity ratio, D/ E" (x3) and "Profitability index of insurance products" (x4).

Graphic interpretation of the integral indicator of economic security assessment of the "Knyazha" Insurance Company ("Княжа") is shown in figure 2. 
Integral indicator of economic security assessment makes it possible to determine the influence of group indicators on the integral indicator, establishes functional correlations between indicators. The level of functional correlation between the indicators of economic security can be differentiated into ranges of values: inverse significant correlation $\in[-1 ;-0,5]$, inverse average correlation $\in(-0,5 ; 0)$, no correlation -0 , direct average correlation $\in(0 ; 0,5]$, direct significant correlation $\in(0,5 ; 1]$. Graphically, the level of functional correlation between the indicators of economic security in three dimensional space can be traced from the peak (in case of direct significant correlation) to the trough (in case of inverse significant correlation).

Based on the calculation of the integral indicator of economic security and the established assessment scale, the effectiveness of the mechanism for managing economic security has been determined. The scale of the integral indicator for assessing the economic security of enterprises is provided by four levels: high $S_{\text {firm }} \in[0,7 ; 1]$, medium $-S_{\text {firm }} \in[0,5 ; 0,69]$, low $S_{\text {firm }} \in[0,3 ; 0,49]$, weak (limited) $-S_{\text {firm }} \in[0 ; 0,29]$.

\section{CONCLUSIONS}

The calculation of the integral indicator of economic security assessment, which is considered as a quantitative measure of the enterprise, taking into account the socio-economic state, has been given. The use of the integral indicator enables to increase the objectivity of assessing the measures to ensure economic security, which directly affects the efficiency of the insurance sector enterprises. The prospects for further study are the development of a matrix of corrective measures for relevant directions of change in the existing system of economic security management at enterprises.

\section{References:}

1. Maslak O. I. Managing the economic bezpekoyu on the principles of protection of the rational situation / O.I. Maslak, N.E. Grishko // Marketing and Innovation Management. - 2013. — № 1. - P. 198-208.

2. Sukhorukov A.I. Theorist-methodological p_dkhid to ingitralno $\ddot{i}$ assessments of the ecofriendly security-free state / A.I. Sukhorukov, Yu.M. Arazishvili // Bankivska on the right. 2011. - № 4. - P. 13-32.

3. Jan, S. R., Shah, S. T. U., Johar, Z. U., Shah, Y., \& Khan, F. (2016). An Innovative Approach to Investigate Various Software Testing
Techniques and Strategies. International Journal of Scientific Research in Science, Engineering and Technology (IJSRSET), Print ISSN, 2395-1990. URL: https://www.researchgate.net/profile/ Fazlullah_Khan2/publication/30328$0520 \_$An_Innovative_Approach_to_Investigate_Various_Software_Testing_Tech$\mathrm{niques}$ and_ Strategies/li n k s/ 576e56e008̄ae842225a849ca.pdf

4. Kirchner E., \& Sperling, J. (2018). EU security governance. URL: https://www.manchesterhive.com/view/9781526130945/9781526130945.xml

5. Lazaridis, G. (2016). Security, insecurity and migration in Europe. Routledge. URL: https:// books.google.com.ua/books?hl=uk\&lr=$\& \mathrm{i} d=\mathrm{kLfeC}$. A A Q B A J \& o $i=f n d \& p g=$ $P P 1 \& d q=+$ economic + security + of + the +state \& ots $=m g b W F s 1 L d W \& s i g=j G e 2 p S-$ ${ }_{\mathrm{wCAnTr}} \mathrm{CDb}$ lr6b3LSqHiM\&redir_esc $=\mathrm{y} \# \mathrm{v}=\mathrm{O}-$ nepage\&q=economic $\% 20$ security $\% 20$ of $\% 2-$ 0 the $\% 20$ state $\& \mathrm{f}=$ false

6. Lee C. (2017). The Asian turbulence: a case study in economic security. In Asia-Europe Cooperation After the 1997-1998 Asian Turbulence (pp. 33-54). Routledge. URL: https:/ /www.taylorfrancis.com/books/e/ 978135 1753999/chapters/10.4324\%2F9781315192079-2

7. Martensson K., \& Westerberg, K. (2016). Corporate environmental strategies towards sustainable development. Business Strategy and the Environment, 25(1), 1-9. URL: https://onlinelibrary.wiley.com/doi/full/10.1002/bse.1852

8. Tetiana H., Chorna M., Karpenko L., Milyavskiy M. \& Drobyazko S. (2018). Innovative model of enterprises personnel incentives evaluation. Academy of Strategic Management Journal. Volume 17, Issue 3, 2018 URL: https:// www.abacademies.org/journals/month-juneyear-2018-vol-17-issue-3-journal-asmj-pastissue.html

9. Tetiana H., Karpenko L., Fedoruk O., Shevchenko, I., \& Drobyazko, S. (2018). Innovative methods of performance evaluation of energy efficiency project. Academy of Strategic Management Journal, 17(2), 112-110. URL: https:// www.abacademies.org/articles/innovativemethods-of-performance-evaluation-of-energyefficiency-projects-7067.html

10. Choi T. M., Chan H. K., \& Yue X. (2017). Recent development in big data analytics for business operations and risk management. IEEE transactions on cybernetics, 47(1), 81-92. URL: https://ieeexplore.ieee.org/abstract/document/ 7378465

Стаття надійщла до редакиії 10.03.2019 p. 